Spring 2019

\title{
Milton, Jerome, and Apocalyptic Virginity
}

Brooke Conti

Cleveland State University, b.conti@csuohio.edu

Follow this and additional works at: https://engagedscholarship.csuohio.edu/cleng_facpub

Part of the Literature in English, British Isles Commons

How does access to this work benefit you? Let us know!

Publisher's Statement

COPYRIGHT: (C) Renaissance Society of America 2019

\section{Original Published Citation}

Conti, Brooke. "Milton, Jerome, and Apocalyptic Virginity." Renaissance Quarterly, vol. 72, no. 1, 2019, pp. 194-230, DOI: https://doi.org/10.1017/rqx.2018.3.

This Article is brought to you for free and open access by the English Department at EngagedScholarship@CSU. It has been accepted for inclusion in English Faculty Publications by an authorized administrator of EngagedScholarship@CSU. For more information, please contact library.es@csuohio.edu. 


\title{
Milton, Jerome, and Apocalyptic Virginity
}

\author{
BROOKE CONTI, Cleveland State University
}

\begin{abstract}
Milton's youthful interest in virginity is usually regarded as a private eccentricity abandoned on his maturation. His "Mask" is often read, analogously, as charting the Lady's movement from temporary virginity to wedded chastity. This essay challenges those claims, arguing that Milton's understanding of virginity's poetic and apocalyptic powers comes from Saint Jerome, whose ideas he struggles with throughout his career. Reading "A Mask" alongside Jerome suggests that Milton endorses the apocalyptic potential of virginity without necessarily assigning those powers to the Lady herself. In later works, Milton modifies and adapts Jerome before finally producing the perfect eremitic hero of "Paradise Regain'd."
\end{abstract}

\section{INTRODUCTION}

MILTON'S YOUTHFUL OBSESSION with virginity is one of the enduring puzzles of his biography. Although scholars disagree about whether this obsession involved an actual vow of virginity, as E. M. W. Tillyard first proposed, most now see in Milton's early poems a complex mythology that links celibacy to prophecy. ${ }^{1}$ From his exaltations of the dead virgins Edward King and Charles Diodati to the seemingly apocalyptic powers of the fictional virgin of A Mask, Milton's ascetics have gifts both poetic and eschatological. Critics have considered the psychological origins of Milton's beliefs, and in recent decades it has been commonplace to read his interest in virginity alongside his many expressions of poetic unreadiness and anxiety; in this reading, Milton's fascination with virginity is part of a willed immaturity, a way of

I am grateful to the Milton Society of America for a 2017 MLA panel that allowed me to present these ideas in preliminary form; to Tobias Gregory, Wendy Beth Hyman, James J. Marino, Austin Busch, Katherine Clark, and David G. Hunter for valuable feedback, advice, or direction in my research; and to the superb editorial staff and outside readers for Renaissance Quarterly, especially John Leonard.

${ }^{1}$ Tillyard, 318-26. Tillyard builds on the slightly earlier work of Hanford and Saurat. Important expansions of Tillyard's argument include Sirluck; Evans, 43-48, 59-60; Kerrigan, 22-72. For pushback against the idea that Milton had any unusual interest in virginity, see Leonard.

Renaissance Quarterly 72 (2019): 194-230 (C) 2019 Renaissance Society of America. doi: $10.1017 /$ rqx.2018.3 
remaining in a state of perpetual youth—and perhaps even avoiding death. ${ }^{2}$ Less attention has been devoted to the literary or intellectual origins of this fascination. The assumption seems to be that Milton's interest in virginity was a private eccentricity: one that might have received inspiration from sources such as Spenser, Plato, or the Bible, but that otherwise had no precise precedent and that vanished upon Milton's maturation as easily as it had come.

It is certainly possible that Milton's interest in virginity was a sign of his immaturity, but this interest did not come out of nowhere and neither did it disappear back into it. Rather, I will argue that his treatment of virginity reflects his deep engagement with Saint Jerome, whose defenses of virginity influenced Christendom for more than a millennium - and Milton for much of his career. That Milton read Jerome is not in doubt, for his prose of the 1640s is peppered with citations. In The Reason of Church-Government (1642) Milton calls Jerome "the learned'st of the Fathers"; in Areopagitica (1644) he references the famous story of Jerome's dream, in which God reproves his excessive devotion to pagan literature; and in the divorce tracts (1643-45) he manages the neat trick of simultaneously lamenting Jerome's devotion to celibacy and marshaling his authority in support of Milton's arguments for divorce and remarriage. ${ }^{3}$ Although we do not know for sure when Milton first encountered Jerome, his fingerprints are all over Milton's early works, and particularly $A$ Mask (1634-37). Scholars have long debated $A$ Mask's exact stance on virginity, but reading the work in light of Jerome's two most famous defenses of virginity, the Letter to Eustochium (epistle 22) and Against Jovinian, makes clearer why many readers have felt the masque's celebration of chastity to be incoherent or undermined from within. ${ }^{4}$ As I will suggest, Milton appears attracted to Jerome's more ecstatic claims for virginity while also taking seriously his warnings about immaturity and presumption. In my reading, $A$ Mask endorses the prophetic and apocalyptic potential of virginity, but without necessarily assigning those powers to the Lady herself.

${ }^{2}$ See Kerrigan, 37-39, 53-54; Kendrick, 46; Quint, 209-10.

${ }^{3}$ For the first two references, see Milton, 1953-82, 1:776-77 and 2:509-10. In The Doctrine and Discipline of Divorce Milton mentions Jerome only in passing as he notes that "for many ages" the church discouraged marriage-which he brings up in order to suggest that England's current marriage laws are just as much of a burden as were the prejudices of that earlier era. In The Judgement of Martin Bucer, however, Milton begins with the snide remark that Jerome, "though zealous of single life more then anough," nevertheless permitted the Roman matron Fabiola to divorce her husband and remarry. In Tetrachordon he similarly claims that in his commentary on Matthew 19 Jerome allows divorce "not only for actuall adultery, but for any cause that may encline a wise man to the just suspicion thereof." Milton, 1953-82, 2:236-37, 448-49, 698.

${ }^{4}$ See, for example, Halpern, 89-97; Thomas, 455-57. 
As deeply indebted as Milton is to Jerome, he seems to go out of his way to obscure those debts. That, too, is part of the story. Milton's treatment of Jerome reflects the essential but precarious place of the church fathers in early modern England. Longing for the authority of the fathers but aware of their limitations, Protestants continually mine their works while assuring their readers that the witness of the fathers is never necessary-just a helpful adjunct to scripture. ${ }^{5}$ For this reason, Milton's apparent reluctance to acknowledge Jerome as a source should not surprise us. Milton certainly does not credit Jerome for his depiction of virginity in $A$ Mask, but Jerome's influence and Milton's ambivalence about that influence appear to have been lifelong; even the great poems of his later years show the imaginative impact of Jerome's ascetic writings. As I shall show, both Paradise Lost (1667) and Paradise Regain'd (1671) reveal a poet who never completely rejected Jerome's ascetic writings, although he may have found ways to make them better conform to a Protestant vision.

\section{CHILDLESS FATHERS}

Recent scholarship has demonstrated how much we still have to learn about early modern England's patristic inheritance, and this is doubly true in the case of Milton. ${ }^{6}$ Contrary to the claims of many later church historians, reverence for and argumentative reliance upon the fathers was not limited to more conservative members of the Church of England; even those who insisted most vehemently on the primacy of scripture often enlisted the fathers to interpret it. $^{7}$ Admired for their biblical exegesis and proximity to the Apostolic Church, the fathers' commentary on New Testament sacramental, ecclesiological, or liturgical practices makes routine appearances in controversial literature. And although the practices of the fathers' own days were treated with more skepticism - belated by hundreds of years, they might not be apostolic and often differed from one another-these too could be appealed to when they appeared plausibly in line with both scripture and the argumentative ends of those citing them. In Jacobean and Caroline England, patristic sources provided Anabaptists with evidence for the importance of catechesis before baptism; those seeking the abolition of the prayer book with proof that the early church

\footnotetext{
${ }^{5}$ For more on the ways that post-Reformation reading and citation practices reflect Protestant attitudes toward patristic authority, see Quantin; Visser, 2011; Ettenhuber.

${ }^{6}$ Poole's recent essay on Milton and Origen is the first sustained consideration of Milton's patristic influences since Pritchard's brief overview in the 1930s. Many other studies take as written Milton's hostility toward the fathers. See, e.g., Lewalski, 2005, 65; Quantin, 257.

${ }^{7}$ See Quantin, esp. 1-18.
} 
used simple, unadorned ceremonies; and Presbyterians with arguments against prelacy. ${ }^{8}$ In the early 1640s, Milton's associates, the Smectymnuuans, appealed to both the Greek and Latin fathers as they prosecuted their case for reforms in church government and the liturgy. ${ }^{9}$ In short, while it was conventional for reform-minded Protestants to accuse their opponents of relying overmuch on patristic witnesses, many of these same writers hastened to secure their own arguments with the authority of the fathers.

Milton's works follow a similar pattern. His antiprelatic tracts bristle with references to the fathers even as he alternately denies their reliability and disputes the interpretations that supporters of episcopacy derive from their works. In Of Reformation (1641), for example, Milton inveighs against those who found their arguments on the fathers-and yet, to make this case, he cites Cyprian, Augustine, Ignatius, Basil, and Athanasius as evidence that the fathers themselves relied on no authority but the Bible. ${ }^{10}$ In other words, even when Milton dismisses the importance of patristic witnesses, they remain vital to his argumentative method. However, because Milton's patristic citations are always driven by his rhetorical needs, these alone cannot give us a reliable sense of which works he knew, much less how they may have influenced him. ${ }^{11}$ As Kristen Poole's work on Milton and Origen suggests, we must look beyond explicit citations. ${ }^{12} \mathrm{~A}$ careful student of both the fathers and Milton who is attentive to larger patterns of reception and interpretation in the period will discover much deeper debts than Milton acknowledges.

Although Augustine has been the focus of most of the limited scholarship that has considered early modern English literature's debts to the fathers, Jerome had a similar claim on the Protestant imagination. ${ }^{13}$ Augustine's near

\footnotetext{
${ }^{8}$ For the Anabaptist use of the fathers, see, for example, Smyth, A3 1 ${ }^{\mathrm{v}}, 31$; Verie Plaine and Well-Grownded Treatise Concerning Baptisme, A2 $1^{\mathrm{v}}-\mathrm{D} 21^{\mathrm{r}}$. Separatist and Presbyterian use of the fathers to counter the liturgy and ecclesiology of the Church of England dates back to the sixteenth century, shows a brief revival around the time of the Hampton Court Conference, and reaches its fullest flowering in the early 1640s; for one group of Presbyterians' use of the fathers in the 1640 s, see next note.

${ }^{9}$ For the witness of the fathers in liturgical matters, see Smectymnuus, 1641a, 7; for church government, see Smectymnuus, 1641a, esp. 26-46, 64-65, 72-74, 87-89; Smectymnuus, 1641b, esp. 76-89. Jerome was particularly useful to Presbyterians because of his assertion, in his commentary on Titus and in several epistles, that in the primitive church bishops and presbyters were the same thing.

${ }^{10}$ Milton, 1953-82, 1:560-66.

${ }^{11}$ Although Milton cites a wide range of fathers, none receives even as many as twenty citations by name (Cyprian gets eighteen and Jerome and Augustine sixteen apiece).

12 Poole, 8-9.

${ }^{13}$ For book-length studies of Augustine's influence, see Ettenhuber; Visser, 2011.
} 
contemporary and sometime sparring partner, Jerome was revered from late antiquity onward. By the sixteenth century, his primary reputation was as a scholar and protohumanist, admired for his insistence on studying scripture in its original languages as well as for his elegant prose and his fusion of classical and Christian learning. ${ }^{14}$ Much of this esteem was due to Erasmus's monumental 1516 edition of Jerome. ${ }^{15}$ Dismissing out of hand the purported miracles that had made up much of the saint's medieval reputation, Erasmus instead celebrated Jerome for his patient elucidation of scripture, holding him up as an antidote to the dull arcana of Scholasticism. Jerome, Erasmus said, wrote as eloquently as Cicero, but put all that was good in the pagan world to the service of Christianity. ${ }^{16}$ Indeed, he maintained that Jerome, with his mastery of many languages, was the superior of Augustine, who had only Latin and a smattering of Greek. ${ }^{17}$

Erasmus's Jerome is, to a large degree, the Protestant Jerome. Sixteenth- and seventeenth-century Protestants admired Jerome chiefly as a translator and exegete, but his epistles, more than one hundred of which survive, were widely read in the humanist classroom. ${ }^{18}$ His lacerating polemical style was also an inspiration for many a controversialist; the fact that his most frequent targets included clerical and monastic corruption and the cesspool of Rome made him particularly popular among reform-minded Protestants—as did his insistence that bishops and presbyters were originally the same thing. Nevertheless, the Reformation did complicate Jerome's reputation. Luther famously objected

${ }^{14}$ For an account of Jerome's changing stature and reputation from late antiquity through the Renaissance, see Rice.

${ }^{15}$ This edition, the first attempt to collect and edit Jerome's complete works, ran to nine folio volumes; Erasmus was responsible for the first four volumes, consisting of the letters and treatises. For more on the history of this endeavor, see Pabel, 2008; Jardine, 55-82; Brady and Olin, xiii-xxxvii.

${ }^{16}$ Erasmus's construction of a humanist Jerome is especially evident in the prefatory epistles and the Life of Jerome that opens the first volume. However, Erasmus was not the first humanist to see Jerome as kindred scholarly spirit (see, for example, McManamon). And, as Rice demonstrates, even in the Middle Ages Jerome's scholarly reputation made up part of his appeal. See Rice, 84-115.

${ }^{17}$ Brady and Olin, 9, 45, 54. Jerome's mastery of Latin, Greek, and Hebrew is generally accepted by scholars today. In the pre- and early modern periods he was often credited with Syriac and Chaldee as well, and sometimes Dalmatian (his supposed native tongue). See Kelly, 134, 159-63; Rice, 139. For a nuanced account of Erasmus's ambivalence toward Augustine, see Visser, 2011, 30-37.

${ }^{18}$ Rice, $90-91$. 
to Erasmus's elevation of Jerome over Augustine, ${ }^{19}$ and Counter-Reformation Catholicism was quick to claim the heretic-hunting polemicist and divinely inspired translator of the Vulgate as a kind of patron saint. ${ }^{20}$ Jerome's wellknown defenses of virginity and the ascetic life posed another problem, although again Erasmus provided a partial way out by emphasizing how different Jerome's asceticism was from the late medieval variety. In the fourth century, Erasmus noted, asceticism was voluntary, required no binding vows, and allowed the individual extraordinary bodily, civic, and intellectual freedom. ${ }^{21}$ Accordingly, Protestant treatment of Jerome remains largely respectful, in keeping with their treatment of the fathers more generally. Frequently they use Jerome's own words as proof that he would not recognize the uses to which his reputation was being put by the Catholic Church.

Milton's sixteen explicit references to Jerome in his prose are in line with the Protestant Jerome for which Erasmus's edition laid the foundation. Indeed, as Sharon Achinstein's work on the divorce tracts suggests, it is probable that Milton encountered Jerome in Erasmus's edition. ${ }^{22}$ But while Milton follows Erasmus in speaking admiringly of Jerome's learning and emphasizing its great distance from dull Scholasticism or credulous superstition, there is one important area in which his esteem differs from the Dutch humanist's. Although Erasmus excused Jerome's interest in sexual asceticism at every opportunity, it is clear that he did not share it; he quibbles with Jerome's more ecstatic claims in his scholia, or notes to Jerome's works, and registers objections even in the text of his Life of Jerome. ${ }^{23}$ Milton, however, says nothing negative about

${ }^{19}$ For a brief summary of Luther's objections to Jerome, see Rice, 139. The discovery of Luther's heavily annotated copy of Erasmus's edition of Jerome, however, suggests that what was once taken as Luther's rejection of Jerome's positions on such things as free will may instead have been Luther's rejection of what he saw as Erasmus's incorrect conclusions about Jerome's positions. For this, see Lössl; Visser, 2017.

${ }^{20}$ The debate over Jerome's translation of the Bible is one of the stranger chapters of his Renaissance afterlife. The Vulgate's many errors and infelicities, combined with the fact that its text is not the one that Jerome quotes in his biblical commentaries, led Erasmus — and many Protestants after him-to argue that the Vulgate could not have been the work of such a talented linguist and exegete; Jerome's actual translation, they concluded, must have been lost. However, post-Tridentine Catholics continued to insist that the Vulgate was Jerome's work and argued that none of its errors concerned matters of faith. Rice, 173-99.

${ }^{21}$ Brady and Olin, 29, 31. The major Reformers all agree with this account of early monasticism. See, for example, Calvin, 478-79 (Institutes 4.13.8).

${ }^{22}$ I am grateful to Professor Achinstein for sharing work from her forthcoming edition for Oxford University Press. As Ettenhuber, 40-41, notes, Erasmus's editions remained the most important source for the works of the Latin fathers well into the seventeenth century.

${ }^{23}$ Brady and Olin, 48, 192-93. See also Pabel, 2002, 475, 478-81. 
Jerome's commitment to celibacy until after his own marriage. In his early poems, he seems to have been inspired by it.

The central features of Milton's asceticism have been teased out of his works by Tillyard, Ernest Sirluck, and David Quint. Based partly on his reading of Revelation 14:1-4, Milton appears to have believed that virginity conferred poetic and prophetic powers. This belief had both present and otherworldly implications: in dedicating himself to celibacy, Milton may have been setting himself apart as a sacred poet destined for an exceptional literary career, but his poems also suggest that virgins participate in the celestial music that was sung at the Creation and would again be sung at the Apocalypse. Along the way he implies that virginity might have the power to undo the Fall and raise the virgin to the state of the angels_or at least save him from death. Nor is virginity the only bodily discipline that interests Milton; in "Elegy Six" and $A$ Mask he suggests that the virgin poet should also keep a vegetarian diet and drink nothing stronger than water. ${ }^{24}$

But although nearly all the critics who have discussed Milton's asceticism emphasize how unusual these beliefs are-Kerrigan sees the young Milton as pathologically neurotic while Quint speaks of his views as a "private myth"in their general outlines, none of these ideas would have seemed strange to the Christian fathers. ${ }^{25}$ As scholars such as Peter Brown and Teresa M. Shaw have shown, the connection between asceticism and the Apocalypse is an ancient one. ${ }^{26}$ Numerous early Christian writers believed that virginity and fasting (singly or in combination) had the power to undo the Fall and usher in the Apocalypse, and the idea that virgins lived or would live the life of the angels was also commonplace; Jesus's statement in Matthew 22:30 that "in the resurrection [humans] neither marry, nor are given in marriage, but are as the angels of God in heaven" was taken as evidence that celibacy was itself angelic. ${ }^{27}$ There

${ }^{24}$ In "Elegy Six," written to his friend Charles Diodati, Milton claims that the poet who wishes to write of divine things should "let herbs afford him harmless sustenance," drink only "moderate draughts from a pure spring," and keep his youth "free of villany and ... chaste": Milton, 2012, 149 (147-49). Quint has linked that ideal to the fantasy of the apocalyptic abolition of time in "On the Morning of Christ's Nativity”: see Quint, 203-04.

${ }^{25}$ In this, Kerrigan and Quint are following Hanford and Tillyard, who speak of how "repugnant" virginity was to Milton's true, "sensuous" nature. Hanford, 143-44; Tillyard, 325; Kerrigan, 51-59; Quint, 209. Rogers is one of the few critics to place Milton's fascination with virginity within the larger tradition of Christian asceticism.

${ }^{26}$ See Brown; Shaw.

${ }^{27}$ Exactly what this meant varied by interpreter. Some early Christian writers believed that the celibate would become like the angels after death, while others believed that they were somehow like them even while on earth. See Brown, 87, 331-38. All biblical quotations are from the Authorized (or King James) Version, unless otherwise noted. 
were, of course, more prosaic reasons that Christians valorized celibacy-they believed that virgins were following the examples of Jesus and Paul, and that (as Paul said) married people were more preoccupied by the things of this world than the things of God-but mystical claims have always been a part of the package.

A number of fathers wrote treatises in favor of celibacy (and/or virginity), but Jerome's were to prove the most influential through the centuries. ${ }^{28}$ They also have some unusual emphases that clearly tie them to Milton's works. One of these is Jerome's reading of Revelation 14:1-4, which describes the rewards of virgins in heaven. Here is the complete passage in the Authorized Version:

And I looked, and, lo, a Lamb stood on the mount Sion, and with him an hundred forty and four thousand, having his Father's name written in their foreheads. And I heard a voice from heaven, as the voice of many waters, and as the voice of a great thunder: and I heard the voice of harpers harping with their harps: And they sung as it were a new song before the throne, and before the four beasts, and the elders: and no man could learn that song but the hundred and forty and four thousand, which were redeemed from the earth. These are they which were not defiled with women; for they are virgins. These are they which follow the Lamb whithersoever he goeth. These were redeemed from among men, being the firstfruits unto God and to the Lamb.

Milton's interest in this passage is well known. His most direct reference comes in An Apology against A Pamphlet (1642), where he remarks that he did not "slumber over that place expressing such high rewards of ever accompanying the Lambe, with those celestiall songs to others inapprehensible, but not to those who were not defil'd with women," but earlier allusions can be found in his poetry. ${ }^{29}$ In $A$ Mask Milton describes virgins as being tutored by angels, who tell them, "in cleer dream, and solemn vision / . . things that no gross ear

\footnotetext{
${ }^{28}$ Not all of Jerome's arguments in favor of virginity are original or exclusive to him, with Tertullian being one particularly important and usually uncredited source (although Tertullian did not share Jerome's ecstatic ideas about physical virginity; he regarded celibate nonvirgins as more meritorious). For Tertullian's influence on Jerome, see Kelly, 183-84. However, even for ideas that he did not originate, Jerome's works were the most frequently cited treatments of virginity throughout the Middle Ages and the power of his rhetoric meant their impact was not limited to monastic culture. For the specifically literary importance of Jovinian, see Silvia and Brennan; Smith.

${ }^{29}$ Milton, 1953-82, 1:892-93. The sentence continues, "which doubtlesse means fornication: For marriage must not be call'd a defilement." Most scholars believe that this addendum reflects an evolution in Milton's thinking by the 1640s, as he moves away from a youthful focus on the inviolate virgin body (and toward his own marriage). See my fuller discussion of this passage later in this essay.
} 
can hear," while in Lycidas (1638) he imagines Edward King's supreme consolation for not having "sport[ed] with Amaryllis in the shade" as his ability to "hear the unexpressive nuptiall Song / In the blest Kingdoms meek of joy and love." ${ }^{30}$ Finally, in Damon's Epitaph (1639) Milton tells the deceased Charles Diodati that "Because blushing modesty and a stainless youthfulness were pleasing to you, because you never tasted the pleasures of the marriagebed, behold, even now virginal honours are reserved for you. You ... will enact for all eternity immortal marriage rites where there is singing and where the lyre, mingled with the dances of the blessed, sounds ecstatically, and the festive revels rave in bacchic frenzy under the Thyrsus of Zion." 31

But although Revelation 14 was a common proof text for those asserting the superiority of virginity to married life, Milton's focus on the song of the 144,000 is unusual. In most early Christian defenses of virginity the important part of the passage is the virgins' greater proximity to the Lamb. For example, in Holy Virginity Augustine expends only two sentences on the fact that virgins will "introduce a new song at the wedding of the Lamb," compared with fourteen describing the places the Lamb goes where only virgins can follow. ${ }^{32}$ Other early references to this passage can be found in Cyprian, Methodius, and Pseudo-Sulpitius Severus, none of whom comment on the virgins' song at all. ${ }^{33}$

For Protestant commentators on the passage, the song is scarcely more important than the literal virginity of its singers. Seventeenth-century England saw a surge of interest in the book of Revelation, which Protestants across the denominational spectrum read as proving that the pope was the Antichrist and that England would have a special role in the eschaton. In the patriotic millenarianism of Milton's political tracts there are signs of the influence of commentators such as Arthur Dent, Thomas Brightman, Hugh Broughton, and Joseph Mede (the last of whom Milton would have known as a tutor at Christ's College, Cambridge). ${ }^{34}$ But when it comes to the

${ }^{30}$ Milton 2012, 81, 53, 57 (Mask 457-58; Lycidas 68, 176-77).

${ }^{31}$ Milton, 2012, 228 (Damon 112-19).

${ }^{32}$ Augustine, 84 (Holy Virginity 27).

${ }^{33}$ Cyprian, 431 (Dress of Virgins 4); Methodius, 330-31 (Ten Virgins 1.5); Pseudo-Sulpitius Severus, 58 (Letter 2.2).

${ }^{34}$ Dent's work, first published in 1603, remained popular for decades; it was reprinted nine times, up through the Interregnum. Mede's Clavis Apocalyptica had a similarly long life. First published in 1627, it was revised and expanded in 1632; received an English translation in 1643; and was reprinted (singly or as part of his Complete Works) through the century's end. Mede was once, erroneously, believed to have been Milton's tutor, but he was indeed a close friend of Milton's actual tutor, William Chappell, and one of the most prominent figures at Christ's College; see Campbell and Corns, 27-28. For more on English apocalyptic thought, see Firth; Jue; Capp, esp. 101-18. 
144,000 and their song, Milton's interpretation diverges markedly from theirs. ${ }^{35}$ Early and mid-seventeenth-century commentaries stick closely to the reading of Revelation 14:1-4 that was popularized in the sixteenth century and exemplified by John Bale's Image of Both Churches (1550). There, Bale explains that the 144,000 are those who are spiritually pure, not defiled with "straunge doctrines, nor yet prophane worshippinges ... [nor] the spousage of their soules have they broken by no fylthye tradicions of men." ${ }^{36}$ The language of seventeenth-century commentators scarcely differs from Bale's (or from the Geneva Bible, which glosses the passage similarly). Nor are Protestant commentators particularly interested in the newness or exclusivity of the song. Broughton describes "the summe of the song" as the Christian message of the Trinity, Fall, incarnation, and resurrection, which is the same song "tolde through all Boukes of the Bible," and Mede explains that it is new only in the sense that it either did not exist before Christ's incarnation or gets sung afterward with a new kind of gladness. ${ }^{37}$ In none of these works are the "virgins" actual virgins, and what is special about the song is only that those who belong to the Beast cannot hear it.

Milton's conviction that virgins have a privileged place in heaven might have come through other patristic sources, but his interest in their song seems indebted to Jerome in particular. In the concluding paragraph of epistle 22, the Letter to Eustochium that I will have more occasion to discuss in a moment, Jerome not only quotes the part of the passage that emphasizes the virgins' musical ability, but he also highlights both the newness of this song and the impossibility of anyone else learning it. After a list of other "rewards" that Eustochium will receive for her perpetual virginity at the last day, Jerome concludes with this vision: "Then shall the 'hundred and forty and four thousand' hold their harps before the throne and before the elders and shall sing the new song. And no man shall have power to learn that song save those for whom it is appointed. 'These are they which were not defiled with women, for they are virgins." 38 In paraphrasing this passage, Jerome, like Milton almost thirteen hundred years later, focuses on the song rather than the virgins' privileged proximity to the Lamb; he also stresses that only some are "appointed" to learn it,

${ }^{35}$ See Dent, 201; Brightman, 392-94; Broughton, 207, 227; Mede, 2.76-84 (Kk2 1v-Ll2 1v).

${ }^{36}$ Bale, l.iii $1^{\mathrm{v}}$. Junius, 178 , provides a similar reading in his own exposition of Revelation, as well as in the marginal notes derived from his work that made their way into the 1599 Geneva Bible. However, the Reformation did not inaugurate the tradition of reading the virginity of the 144,000 in a nonliteral fashion; in the fourteenth century, Nicholas of Lyra suggests that virginity may merely mean continence: Lyra, 162.

${ }^{37}$ Broughton, 207; Mede, 2.81-83 (Ll 1 $\left.{ }^{\mathrm{r}}-\mathrm{L} 121^{\mathrm{r}}\right)$.

${ }^{38}$ Jerome, 1994b, 6:41 (Eustochium 41). 
and he removes Revelation's qualifying "as it were" ("quasi") that modifies the "new song" that the virgins sing. ${ }^{39}$ For both men, divine song is a central reward of virginity.

In Against Jovinian, Jerome's other major defense of virginity, he expands on the poetic powers of virgins-and implies that they need not wait for the afterlife to achieve them. A blistering attack on a man Jerome paints as a dangerous libertine, Jovinian contains some of the most dramatic claims for virginity in patristic literature. ${ }^{40}$ As in Eustochium, in Jovinian Jerome cites Revelation $14: 1-4$ as evidence of the unique powers of virgins. But in an extraordinary passage celebrating Revelation's putative author, Jerome declares that John did not merely describe the ability of virgins to sing a new song, but, as the inspired writer of the fourth Gospel, the book of Revelation, and the epistles that bear his name, John is himself proof of the unmatched literary powers of virgins. That the beloved disciple of Jesus, John the Evangelist, and John the Divine were all the same person was widely accepted by Christians, and there was a tradition that John had never married. But Jerome foregrounds John's supposed virginity and makes it central to all his attainments. Unlike the other disciples, Jerome says, John "was a virgin when he embraced Christianity, remained a virgin, and on that account was more beloved by our Lord." 41 That John's virginity was the reason for Jesus's great love is an original argument, something Jerome tacitly acknowledges by almost immediately going on the defensive. If Jovinian should say otherwise, he blusters, "let him explain, if [John] was not a virgin, why it was that he was loved more than the other Apostles." 42 Nor does Jerome stop here, insisting that John is the superior even of Peter. As he says, "Peter is an Apostle only, John is both an Apostle and an Evangelist, and a prophet." 43 The nature of John's literary output is further testimony to the visionary and prophetic powers of virgins. Whereas the three synoptic Gospels begin with earthly concerns - the pregnancy of Zacharias and Elizabeth; John the Baptist's ministry; Jesus's genealogy—John's Gospel, like the book of Revelation, "soars aloft," flying up to "the Father Himself." 44 As

${ }^{39}$ In his line-by-line commentary on the epistle, Adkin, 406-07, notes the ways in which Jerome's Latin paraphrase differs from the Vulgate.

${ }^{40}$ Although none of Jovinian's works have survived, he appears simply to have insisted that celibacy was no more estimable than married life. As D. G. Hunter has argued, Jovinian was probably voicing a mainstream position, but Jerome launched such a lengthy and intemperate counterattack that the impression of Jovinian that has come down through the ages is of a flagrant libertine.

\footnotetext{
${ }^{41}$ Jerome, 1994b, 6:365 (Jovinian 1.26).

${ }^{42}$ Jerome, 1994b, 6:366 (Jovinian 1.26).

${ }^{43}$ Jerome, 1994b, 6:366 (Jovinian 1.26).

${ }^{44}$ Jerome, 1994b, 6:366 (Jovinian 1.26).
} 
Jerome concludes, "the virgin writer expounded mysteries which the married could not." ${ }^{45}$ In his insistence on the connection between virginity and literary talent, Jerome's appeal to Milton should be plain. ${ }^{46}$

Jerome's focus on John leads him to another claim for virginity that will also be familiar to readers of Milton. In his zeal to separate the virgin John from all the other apostles, Jerome declares that John never died-and he strongly implies that the same might be true for other virgins. As Jerome notes, Jesus predicted in John 21:18-23 that Peter would be martyred but that John would have a different fate; this ambiguous remark, the Gospel says, gave rise to a rumor "among the brethren, that that disciple should not die." Although the Gospel goes on to undercut this rumor (and most later commentators cautioned against taking it seriously), Jerome takes John's miraculous avoidance of death as an established fact and then draws from it a still more startling conclusion: "Here we have a proof that virginity does not die, and that the defilement of marriage is not washed away by the blood of martyrdom, but virginity abides with Christ, and its sleep is not death but a passing to another state." ${ }^{47}$ In other words, being a virgin not only saves one from death, but is more meritorious than even the martyrdom of a nonvirgin. ${ }^{48}$

Although it is not clear that Milton ever believed virginity had power over death, he toys with the idea in some early works. His first surviving English poem, "On the Death of a Fair Infant Dying of a Cough" (1628), emphasizes the young child's virginity, implies that it might save her body from corruption, and briefly floats the possibility that she was an angel. ${ }^{49}$ According to David Quint's reading of "Elegy Six" and "On the Morning of Christ's Nativity"

${ }^{45}$ Jerome, 1994b, 6:366 (Jovinian 1.26).

${ }^{46}$ In his analysis of Jerome's possible sources for Jovinian, Duval, 177-78, finds no clear precedent for his treatment of John.

${ }^{47}$ Jerome, 1994b, 6:366 (Jovinian 1.26). The Bible does not fully debunk this rumor, but it suggests that the disciples have misinterpreted Jesus's words: "yet Jesus said not unto him, [John] shall not die; but, If I will that he tarry till I come, what is that to thee?" (John 21:23). Both because of this passage and because John the disciple was presumed to have survived to write the book of Revelation many years later, Christian tradition held that he was the only one of the disciples not to be martyred.

${ }^{48}$ Both of these claims drew swift condemnation from Jerome's original audience, including friends who urged him to write a retraction. He did not. See D. G. Hunter, 249-50; Brown, 429.

${ }^{49}$ The child's virginity and possibly incorruptible body are emphasized in Milton, 2012, 235-36 (10-21, 29-35). Although the headnote to the poem says "Anno aetatis 17," the subject is almost certainly the death of Milton's two-year-old niece, Anne Phillips, who died in 1628 , when Milton was nineteen. For a discussion of the continuities between this poem and $A$ Mask, see Kerrigan, 33-34. 
(1629), Milton raises similar ideas in those poems of the following year, where he suggests that the "noncarnal or virgin verse" of the ascetic poet might allow him to participate in the song of the angels, undo the effects of the Fall, and cheat death. ${ }^{50}$ It is possible that these poems are evidence of an early encounter between Milton and Jerome, or they may simply suggest why Milton was so receptive to Jerome's writings whenever he later encountered them. But by 1634 he clearly had: even the earliest version of $A$ Mask alludes to Jerome's defenses of virginity and the allusions grow with the poem's 1637 revision. ${ }^{51}$ Over the next two years, with Lycidas and Damon's Epitaph, Milton returned to some of the same ideas. In those three works there is no particular suggestion that virginity might protect one from death; it certainly didn't save King or Diodati. Instead, Milton doubles down on the compensatory Johannine fantasy of the virgin poet-prophet and the special place waiting for him in heaven.

Milton would not have been the first poet to see John as a kindred artistic spirit, but Jerome's John is more than that. Writers such as Hildegard of Bingen, John Gower, and the Pearl poet occasionally allude to John or suggest some similarities between his visions and theirs, while in canto 29 of the Purgatorio Dante makes a potentially more direct claim for his equivalence with John. ${ }^{52}$ In all these cases, however, John's primary function is to provide a warrant for poetic speech: the latter-day writer wishes to assert that he too is inspired by God or that poetry is akin to prophecy. ${ }^{53}$ By comparison, in Jerome's mediation of Revelation, the status of John and the 144,000 is imagined as simultaneously rarer than that of a poet or prophet-they are angelic, virginal, and Christ's nearest and dearest-and somehow attainable, insofar as virginity is the key to all their privileges.

In addition to his claims for virginity's prophetic powers, there are other ways Jerome might have contributed to the young Milton's self-fashioning. Ernest Sirluck has linked Milton's attachment to virginity to his decision to pursue a poetic rather than a clerical career, proposing that Milton made a private

${ }^{50}$ Quint, 200, 204-10.

${ }^{51}$ In referring to the "earliest version" of the masque, I mean both the Bridgewater manuscript, which reflects the masque as performed in 1634, and the version in the Trinity College manuscript, which is believed to reflect Milton's original text before any performance-related cuts or changes. In only one case do the manuscripts differ in the passages under discussion here. For a parallel-text edition of the Trinity manuscript, the Bridgewater manuscript, and the 1637 printing, see Milton, 1973.

${ }^{52}$ See Emmerson; Sandler, 171; Hawkins, 62-64. For a consideration of other ways that John's works might have influenced Milton, see Cefalu, 159-70.

${ }^{53}$ For a thoroughgoing consideration of the ways that Revelation (and, to a lesser degree, John) might have served as a literary model for Milton, see Wittreich. For an investigation of Milton's lyric form and its relationship to Apocalypse, see Netzley. 
vow of virginity as the sign and seal of his new vocation. ${ }^{54}$ Although Sirluck dates this decision to the late 1630s and consequently does not consider earlier evidence of Milton's interest in virginity, he is perceptive in linking virginity to Milton's sense of poetic calling. Whenever Milton may have first tied virginity to poetic prowess, I believe that Sirluck is right that it gained additional importance as Milton abandoned his pursuit of the ministry. Here, too, Jerome may have played a role. With his towering erudition and fusion of classical and Christian learning, Jerome the intellectual would surely have appealed to Milton as much as he had to Erasmus. But the monk who decried clerical corruption and championed lay asceticism might have been even more attractive to Milton in the period when he decided against the ministry. ${ }^{55}$ Taking Jerome as an inspiration, Milton could have seen lay virginity as directly opposed to Laudian clericalism and ceremonialism. When combined with the promise of literary and prophetic powers, Jerome's writings on virginity might have helped Milton to figure poetry as a superior kind of religious vocation: ascetic, prophetic, and elect above the rest.

\section{NOT PRIDE BUT FEAR}

If Milton was inspired by Jerome's rhapsodic account of virginity in Jovinian, he also seems to have taken seriously the cautions in Jerome's earlier Letter to Eustochium. In that work, written to the young noblewoman Julia Eustochium, Jerome emphasizes that physical virginity is a necessary but by no means sufficient condition for true virginity. Accordingly, although he celebrates his addressee's decision to commit herself to a life of celibacy, he warns her about its perils and paints the city of Rome in lurid and lascivious colors. Reading A Mask alongside Jerome's two most important defenses of virginity helps explain the ambivalence that critics have long seen in the poem's attitude toward chastity. The central problems have always been: if virginity has the magical powers that the Lady and the Elder Brother claim, then why does she wind up in Comus's thrall? Why can't she free herself? And why does she never unleash the apocalyptic speech that-in the 1637 version-she professes to have? Milton's revisions to the poem add another layer of complexity. Whereas the earlier version might be read as celebrating chastity in its more capacious, Protestant sense, the 1637 version, and in particular the Lady's speech about "the sage and serious doctrine of virginity," insists on a narrower

\footnotetext{
${ }^{54}$ Sirluck, 766-68.

${ }^{55}$ Jerome was eventually and reluctantly ordained, but he referred to himself as a monk, not a priest, for the rest of his career. See Kelly, 58.
} 
interpretation of sexual continence. Many critics therefore assume that the later version reflects a shift in Milton's thinking. ${ }^{56}$

The most common way of accounting for these complexities has been to argue that, one way or another, the masque winds up subordinating virginity to married chastity: the Lady is proven virtuous, but virginity can't live up to its billing. Some critics argue that Milton's undermining of virginity is conscious and others that it is inadvertent, but the fact that the Lady cannot free herself, combined with her return to her father's house and the epithalamic associations of the masque genre itself, serves to reinscribe her within the heterosexual marriage economy. ${ }^{57}$ However, to read the poem in this way is to assume that Milton intends the Lady as a perfect avatar of virginity - and that if she fails, the poem's claims about virginity likewise fail. Such an idea would strike Jerome as bizarre. His Letter to Eustochium makes clear that true virginity requires both discipline and self-knowledge, and he warns her of the dangers of pride and presumption. ${ }^{58} \mathrm{I}$ believe that $A$ Mask borrows from both Jovinian and Eustochium, taking the ecstatic claims of the former and testing them in accordance with the cautions of the latter. In my reading, the poem never abandons the idea that the virgin body might be both inviolate and a vessel for divine poetic speech; at the same time, it dramatizes how difficult these achievements are and how easily undermined from within.

Although the connection between Milton's works and Jerome's Jovinian must be inferred from the similarities between the two men's mystical ideas about virginity, Areopagitica indicates that Milton had read Eustochium by 1644 and I believe that $A$ Mask proves he had read it by 1634 . The first possible point of connection between the epistle and Milton's poem comes in Eustochium's second paragraph, with Jerome's salutation. He hails the letter's recipient as "Lady Eustochium," drawing attention to this apparently unexpected title by explaining, "I am bound to call my Lord's bride 'lady." "59 But although he praises her, here and throughout, Jerome is anxious to impress upon Eustochium the dangers that come with virginity. Christians, he says,

${ }^{56}$ Milton, 2012, 94 (Mask 786-87). That Milton's revisions reflect both a more extreme position on virginity and a change in his own attitude is commonplace. See, for example, Sirluck, 763-65; Rogers, 229-33.

57 The idea that the poem celebrates marriage is widespread, though some critics see this as a gain (because it signals that the Lady and/or Milton have matured past their virginity fixation) and others as a loss (virginity allows the Lady a kind of self-determination that marriage will not). See Kerrigan, 51-61; Halpern; Kim; Shullenberger, 2001; Orgel, 42-44.

${ }^{58}$ Eustochium and Jovinian were written nearly a decade apart, the former in 384 CE and the latter in $393 \mathrm{CE}$. However, the generic demands of the familiar letter versus those of satire probably account for most of the differences in tone and emphasis between the two.

${ }^{59}$ Jerome, 1994b, 6:23 (Eustochium 2). 
"are hemmed in by hosts of foes, our enemies are upon every side." ${ }^{00}$ It soon becomes clear that these enemies are more internal than external: "So long as we are held down by this frail body, so long as we have our treasure in earthen vessels; so long as the flesh lusteth against the spirit and the spirit against the flesh, there can be no sure victory." 61 Jerome then quotes several passages of the Bible in rapid succession, describing the temptations of the flesh in language that suggests a rape: "Our adversary the devil goeth about as a roaring lion seeking whom he may devour"; he "looks not for unbelievers... . It is the church of Christ that he 'makes haste to spoil."'62 But despite the language of appetite and despoliation, Jerome does not seem to imagine actual men as a threat to Eustochium; rather, the danger lies with her own desires, externalized as assaults from the devil. For a long while he speaks of the way Paul's "members warr[ed] against the law of his mind, [seeking] to bring[ ] him into captivity to the law of sin," before turning to his own temptations in the Syrian desert. ${ }^{63}$ As Jerome writes, though with "no companions but scorpions and wild beasts, I often found myself amid bevies of girls." 64 Bringing the discussion back to his young female protégée, Jerome asks, "if such are the temptations of men who, since their bodies are emaciated with fasting, have only evil thoughts to fear, how must it fare with a girl whose surroundings are those of luxury and ease?" 65

If these warnings seem echoed by Milton's masque, so too do Jerome's suggested aids to temperance. The first thing Jerome recommends is that Eustochium "avoid wine as you would avoid poison. For wine is the first weapon used by demons against the young.... Other vices we easily escape, but this enemy is shut up within us, and wherever we go we carry him with us. Wine and youth between them kindle the fire of sensual pleasure." ${ }^{\prime 66} \mathrm{He}$ also counsels Eustochium to temperance in her other appetites ("take food in moderation, and never overload your stomach"; "abstinence may bring back to Paradise those whom satiety once drove out"); urges her to "never incline [her] ear to words of mischief [;] for men often say an improper word to make trial of a virgin's steadfastness"; and suggests that it is only "foolish virgins" who "stray

${ }^{60}$ Jerome, 1994b, 6:23 (Eustochium 3).

${ }^{61}$ Jerome, 1994b, 6:23 (Eustochium 4).

${ }^{62}$ Jerome, 1994b, 6:23 (Eustochium 4).

${ }^{63}$ Jerome, 1994b, 6:24 (Eustochium 5).

${ }^{64}$ Jerome, 1994b, 6:25 (Eustochium 7). A more accurate translation of choris ... puellarum would be dancing girls, or even a chorus of girls - which would place Jerome's tempters in interesting opposition to the 144,000 singing virgins of Revelation (or align them with Comus's revelers).

${ }^{65}$ Jerome, 1994b, 6:25 (Eustochium 8).

${ }^{66}$ Jerome, 1994b, 6:25 (Eustochium 8). 
abroad." 67 Summing up the dangers that beset virgins, he says, "I would have you draw from your monastic vow not pride but fear. You walk laden with gold; you must keep out of the robber's way." ${ }^{68}$ I will come back to that last quotation shortly, as I believe Milton echoes it in his masque, but Eustochium's rapid oscillations from praise to admonition may help us to better understand $A$ Mask's similarly ambivalent characterization of virginity.

In Milton, as in Jerome, the dangers the virgin faces are mostly internal. Reading the poem alongside Eustochium suggests that if the Lady's virginity is sincere, it may still be somewhat foolhardy; like Spenser's Redcrosse Knight in Errour's Wood, she misunderstands the relationship between virtue and temptation. ${ }^{69}$ Accordingly, when the lost Lady hears "the sound / Of Riot, and ill manag'd Merriment" somewhere off in the dark, she heads toward the music even though she professes to be "loath / To meet the rudenesse" that she anticipates. ${ }^{70}$ When she cannot find the revelers, her imaginings take a darker turn. "A thousand fantasies," the Lady says,

Begin to throng into my memory

Of calling shapes, and beckning shadows dire,

And airy tongues, that syllable mens names

On Sands, and Shoars, and desert Wildernesses. ${ }^{71}$

Although these fantasies may have been inspired by the noises she hears in the distance, what the Lady actually describes are her own self-generated imaginings; indeed, her use of the word "memory" implies that these may not be new, but instead recurrent fantasies. ${ }^{72}$ They also sound similar to what Jerome experienced in the "desert Wilderness" of Syria, where shapes and shadows (in his case, "bevies of girls") enticed him to lustful thoughts. Neither in heading toward the music nor in these later fantasies does the Lady seem to fear violence; the worst she expects initially is rudeness, and now what she fears is seduction — that she will respond to the "calling shapes, and beckning shadows"

${ }^{67}$ Jerome, 1994b, 6:28, 26, 31, 33 (Eustochium 17, 10, 24, 26).

${ }^{68}$ Jerome, 1994b, 6:23 (Eustochium 3).

${ }^{69}$ Spenser, 9-10 (Faerie Queene 1.1.12-14). There is a large body of scholarship comparing $A$ Mask with Spenser's epic, although books 2 and 3 are usually seen as more important sources for Milton than book 1.

${ }^{70}$ Milton, 2012, 70, 71 (Mask 172, 177-78).

${ }^{71}$ Milton, 2012, 72 (Mask 205-09).

72 The idea that the Lady's approach toward the music and the fantasies that follow are signs of her own erotic desire has been suggested by several critics, although usually her desire is read as a positive sign, in keeping with readings of the poem that focus on the Lady's sexual agency or maturation. See, for example, Greteman, 428; Kim, 16; Shullenberger, 2001, 36-37; Thomas, 435, 451. 
that have been known to "syllable mens names." In other words, she fears exactly what Jerome and the other desert ascetics encountered: not a rape, but a temptation. ${ }^{73}$

The Lady quickly recovers from these anxieties, but she does so by making claims about chastity that seem to be exactly what Jerome warns Eustochium against doing when he says, "I would have you draw from your monastic vow not pride but fear." She declares that her fantasies

may startle well, but not astound

The vertuous mind, that ever walks attended

By a strong siding champion Conscience.-

O welcom pure-ey'd Faith, white-handed Hope,

Thou hovering Angel girt with golden wings,

And thou unblemish't form of Chastity. ${ }^{74}$

Although Jerome would surely agree with Milton's Lady that chastity and a virtuous mind are powerful and necessary defenses, his Letter to Eustochium suggests that he would caution her against this kind of overconfidence-especially when the Lady continues with the assertion that she fears nothing because "the Supreme good" "Would send a glistring Guardian if need were / To keep my life and honour unassail'd." 75 As Jerome knew only too well, the desert ascetics wrestled ferociously with lust, and though they may eventually have prevailed, whatever supernatural assistance they received did not take the form of a "glistring Guardian."

Even the Elder Brother, who is usually remembered for his yet more rhapsodic claims for chastity, is not quite as bold as his sister. In reassuring the Younger Brother about the Lady's safety, he declares that the chaste woman "is clad in compleat steel" and may go anywhere at any time, even "where very desolation dwels," but then he inserts a key caveat: "Be it not don in pride, or in presumption." ${ }^{\text {" }} \mathrm{A}$ few lines later he reiterates this caution as he asserts that "No goblin, or swart Faëry of the mine, / Hath hurtfull power o'er true virginity." 77 Like Jerome, who insists that virgins can lose their purity with a single lustful thought, the Elder Brother admits that not all virgins are saved by virtue of their celibacy. ${ }^{78} \mathrm{He}$ also implies that there is a particular danger attendant upon an overconfident or presumptuous virginity.

${ }^{73}$ As Orgel notes, all of Comus's bestial followers seem to be volunteers-they were willingly seduced: see Orgel, 35 .

${ }^{74}$ Milton, 2012, 72 (Mask 210-15).

${ }^{75}$ Milton, 2012, 72 (Mask 217, 219-20).

${ }^{76}$ Milton, 2012, 80 (Mask 428-31).

${ }^{77}$ Milton, 2012, 80 (Mask 435-36).

${ }^{78}$ See Jerome, 1994b, 6:24 (Eustochium 5). 
The Younger Brother sounds an even louder cautionary note, which likewise seems to echo Jerome. When the Elder Brother obliquely compares their lost sister to a monastic — one who might actually prefer "sweet retired Solitude" and "Contemplation"79- the younger continues the ascetic imagery, agreeing that "musing meditation most affects / The Pensive secrecy of desert cell" and that no one would "rob a Hermit of his Weeds, / His few Books, or his Beads, or Maple Dish." 80 Even though the Younger Brother will go on to assert that his sister is not as safe as a hermit, the otherwise puzzling emergence of this monastic language strengthens the poem's investment in Christian asceticism. In fact, I suspect the Younger Brother is alluding to Jerome directly in his subsequent lines. "Beauty," the Younger Brother says,

like the fair Hesperian Tree

Laden with blooming gold, had need the guard

Of dragon watch with uninchanted eye,

To save her blossoms, and defend her fruit

From the rash hand of bold Incontinence.

You may as well spred out the unsun'd heaps

Of Misers treasure by an out-laws den,

And tell me it is safe, as bid me hope

Danger will wink on Opportunity,

And let a single helpless maiden pass

Uninjur'd in this wilde surrounding wast. ${ }^{81}$

In comparing "a single helpless maiden" to "heaps / Of Misers treasure" laid beside "an out-laws den," the Younger Brother articulates a version of Jerome's admonition to Eustochium that she should "draw from [her] monastic vow not pride but fear" because she "walks laden with gold" and therefore "must keep out of the robber's way." ${ }^{2}$ As I have noted, however, in Jerome's scenario the "robber" is not a rapist, but the devil, which is to say Eustochium's own susceptibility to lust. Even if the Younger Brother were himself envisioning an assault by a predator, the poem demonstrates that "the rash hand of bold Incontinence" may actually be the Lady's. The disagreement between the two brothers is therefore not as extreme as it is sometimes characterized; the Elder Brother does not claim that virginity automatically generates an impenetrable force field, nor does the Younger say that it magnetically attracts rapists. Milton does sever Jerome's more rhapsodic claims about

\footnotetext{
${ }^{79}$ Milton, 2012, 78 (Mask 376-77).

${ }^{80}$ Milton, 2012, 78 (Mask 386-91).

${ }^{81}$ Milton, 2012, 78-79 (Mask 393-403).

${ }^{82}$ Jerome, 1994b, 6:23 (Eustochium 3).
} 
virginity from his more cautionary ones, giving most of the former to the Elder Brother and most of the latter to the Younger, but they are in dialogue more than opposition. Together they help the reader to consider the power, potential, and limitations of virginity.

Read in this light, Comus is not so much an assailant as a tempter: someone who appeals to desires the Lady already has. When he first detects the Lady's footsteps, Comus tells his crew that his seduction technique depends on "well plac't words of glozing courtesie, / Baited with reasons not unplausible"—or, as Jerome says in Eustochium, "men often say an improper word to make trial of a virgin's steadfastness." ${ }^{83}$ Elsewhere Comus's language makes clear that he has set himself up as the antithesis of the ascetic discipline that Jerome advocates. Just fourteen lines into his first speech Comus identifies himself as the natural enemy of "Rigor" and "Severity," and later in the masque, as he attempts to persuade the Lady to drink of his cup, Comus speaks of her "cruel[ty] to [her] self"; describes chastity as "lean and sallow Abstinence"; and imagines her as preferring to "feed on Pulse, / drink the clear stream, and nothing wear but Freize." 84 Though this language of "cruelty" is intended to persuade the Lady to abandon her resolve, his words, like the brothers' strange sidebar about the happiness of a hermit in his cell, invite us to envision the Lady as a monastic clad in coarse cloth and subsisting on water and lentils, like the desert ascetics. Indeed, in rejecting the Lady's arguments for the "doctrine of Virginity," Comus describes such a life as "direct / Against the canon laws of our foundation," a formulation that presents his own lifestyle as a perverted or parodic kind of monasticism. ${ }^{85}$ This only highlights how much more truly ascetic hers is.

But although Comus tries to present virginity as something repressive and limited, no one in the poem, Comus included, seems to believe it. Rather, the masque repeatedly presents virginity as a source of power. Just as Jerome argues that virginity has prophetic and apocalyptic powers that permit commerce with the angels, so at different moments do Comus, the Lady, and her Elder Brother. At the beginning of the poem Comus senses the presence of a virgin even before he can see her, suggesting that she gives off some kind of perceptible spiritual emanations; then, when he hears her sing, he declares that "somthing holy lodges in [her] brest" and speculates that she may not even be mortal. ${ }^{86}$ The Lady, as I have noted, speaks of expecting the aid of a

${ }^{83}$ Milton, 2012, 70 (Mask 161-62); Jerome, 1994b, 6:31 (Eustochium 24).

${ }^{84}$ Milton, 2012, 68, 90, 91 (Mask 107-09, 679, 709, 721-22).

${ }^{85}$ Milton, 2012, 94 (Mask 787, 807-08). See also Comus's earlier description of himself and his followers as the "vow'd Priests" of Cotytto: Milton, 2012, 69 (Mask 129).

${ }^{86}$ Milton, 2012, 69-70, 73 (Mask 145-49, 244-46). 
"glistring Guardian," and her brother makes a similar claim, saying that "So dear to Heav'n is Saintly chastity, / That when a soul is found sincerely so / A thousand liveried Angels lacky her." 87 Although this statement comes with another of the Elder Brother's caveats about virgins needing to be sincere to receive such assistance, it is still an extravagant claim. ${ }^{88}$ Not only will angels assist the true virgin, he says, but they will also take her under their tutelage,

And in cleer dream, and solemn vision [they will]

Tell her of things that no gross ear can hear,

Till oft convers with heav'nly habitants

Begin to cast a beam on th'outward shape,

The unpolluted temple of the mind,

And turns it by degrees to the souls essence,

Till all be made immortal. ${ }^{89}$

The last lines of this passage may prefigure the monism of Milton's later years, with the vision of the virtuous soul ascending up the great chain of being to the state of the angels, but the earlier lines seem to gesture toward Revelation $14: 1-4$ and the 144,000 virgins who learn a new song that no one else can know. Virginity links these two ideas, allowing the celibate to communicate with the angels, which in turn sublimes the virgin body into pure, immortal soul.

The Lady goes even further. Whereas her brother says that angels will assist the sincere virgin, in Milton's 1637 revision the Lady claims independent prophetic and apocalyptic powers. If she were to disclose "the sage / And serious doctrine of Virginity," she tells Comus,

this pure cause would kindle my rap't spirits

To such a flame of sacred vehemence,

That dumb things would be mov'd to sympathize,

And the brute Earth would lend her nerves, and shake,

Till all thy magick structures rear'd so high,

Were shatter'd into heaps o're thy false head. ${ }^{90}$

Just as Jerome claims that John "expounded mysteries that the married could not," the Lady asserts that her virginity is linked to a sacred vehemence with

${ }^{87}$ Milton, 2012, 72, 81 (Mask 219, 453-55).

${ }^{88} \mathrm{It}$ is worth bearing in mind the older definition of sincere: "Pure, unmixed; free from any foreign element or ingredient" (see Oxford English Dictionary, s.v. "sincere," adj. 2; also cf. 1c., "Morally uncorrupted, uncontaminated").

${ }^{89}$ Milton, 2012, 81 (Mask 456-63).

${ }^{90}$ Milton, 2012, 94 (Mask 786-87, 794-99). 
world-shattering consequences. Nor is this her impression alone. Comus, who earlier seemed to link the Lady's virginity to something merely vaguely mystical, is here sufficiently shaken by the force of her eloquence to say:

She fables not, I feel that I do fear

Her words set off by som superior power; ... a cold shuddering dew

Dips me all o're, as when the wrath of Jove

Speaks thunder, and the chains of Erebus

To som of Saturns crew. ${ }^{91}$

What Comus feels in her words is the power of a vengeful god to cast demons down to the underworld.

Apart from this exchange about the "sage and serious doctrine of virginity" and its apocalyptic potential, all the passages I have previously discussed exist in the earlier version of the masque. ${ }^{92}$ This suggests that Milton's most significant addition to his masque in 1637 represents not a change in his attitude toward virginity, but an upping of the stakes. All versions of the poem are in dialogue with Eustochium and all seriously consider the possibility that virginity, properly managed, might raise one to the level of the angels. What the new passage seems to add is the idea that the virgin might also, like John, be an earthly poet-prophet: one whose "pure cause" allows him to go Orpheus one better, inspiring the earth not just to sympathize but to overthrow the old order ("Saturns crew"). This ecstatic possibility might seem to take Jovinian's Johannine claims literally, but Milton does not alter the poem in other ways - for example, by allowing the Lady to free herself. Many critics have suggested that the fact that the Lady does not unleash her supposedly apocalyptic speech upon Comus and remains glued to her chair demonstrates the insufficiency of Milton's doctrine of virginity. As I have been arguing, however, these are not necessarily signs of virginity's insufficiency, but of the Lady's. ${ }^{93}$ After all, it is not her brothers or the Attendant Spirit who rescue her, but the nymph

${ }^{91}$ Milton, 2012, 94 (Mask 800-01).

${ }^{92}$ The only passage I have discussed that is not in both the Trinity and Bridgewater manuscripts is at lines 205-20, starting with the Lady's description of her fears ("A thousand fantasies") through her declaration that a "glistring Guardian" will protect her. That passage is in the Trinity manuscript alone (and is restored in 1637). See Milton, 2012, 94 (Mask 786-87); Milton, 1973, 72-76.

${ }^{93} \mathrm{My}$ argument is therefore nearly the opposite of Shuger's, although she likewise reads the poem in terms of possible patristic influences. Based on Augustinian and later treatments of wet dreams, Shuger argues that the Lady, though desiring, is not morally culpable because her will was not implicated. See Shuger, 1997. For another reading of the poem that, like mine, sees the Lady's pride as undermining her chastity, see Lander Johnson, 141-43, 164-66. 
Sabrina, who actually was made immortal through her virginity and who has powers greater than anyone else in the poem. ${ }^{94}$

Reading the masque alongside Jerome's Eustochium and Jovinian suggests that the primary problem with the Lady's virginity is that it is still immature and overconfident. In Jerome's words, she places herself in the robber's way because she has taken the wrong lesson from her virginity: pride in her apparent virtue rather than fear for her necessarily frail flesh. This is not a condemnation of either the Lady or virginity; after all, in Lycidas and Damon's Epitaph Milton will redouble his claims for virginity's poetic and eschatological power. What the 1637 revision shows is Milton's continuing attraction to virginity and perhaps a yet more fervent commitment to the idea that it might-for some people, in some circumstances-be accompanied by apocalyptic and even death-defying powers. However, Milton takes seriously the caveats with which Jerome hedges his more extravagant claims. There are a lot of virgins; not many will consort with angels and gain the gift of prophetic speech. But the young Milton may still hope to be among them.

\section{THOUGH COMMONLY NOT SO THOUGHT}

Jerome's defenses of virginity are not obscure texts, but that scholars have not previously connected them to Milton's works is at least partly due to Milton himself. One way he elides Jerome's influence is by merging his treatments of virginity with pagan pastoral so thoroughly that their Christian elements can seem difficult to identify. ${ }^{95}$ But it is the autobiographical passage in $A n$ Apology against a Pamphlet that makes plain how deliberate Milton's occlusion of Jerome really is. In this work, whose chief purpose is to continue his war against the bishops, Milton provides a strangely detailed autobiographical response to an opponent who has tried to discredit him by insinuating that he haunts theaters and bordellos. Milton denies the charge, launches into a

\footnotetext{
${ }^{94}$ What Sabrina symbolizes and how this second virgin comments on the Lady's virtue is by no means settled. Early readings of the poem as a Christian allegory tended to argue that she represented divine grace, while more recent readings have been interested in the possibility of female sympathy between the two characters. It is puzzlingly common, however, for critics to ignore or downplay the importance of Sabrina's virginity, even calling her role "maternal" (Shullenberger, 2003, 184, 194), "motherly" (Kendrick, 51), akin to that of a "midwife" (Brogan, 38), or otherwise seeing her as guiding the Lady from immature virginity to wedded chastity. See also Kim; Lewalski, 2005, 80-81.

${ }^{95}$ Numerous critics over the years have argued either that $A$ Mask's theology is not Christian or that its fusion of pagan and Christian theologies accounts for the poem's allegedly incoherent treatment of chastity. See Saurat, 16; Kerrigan, 57-59; Halpern, 89-92; Kendrick, 46, 69; Shuger, 2012, 143-44.
} 
lengthy discussion of his esteem for sexual continence, and then walks the reader through the intellectual and literary origins of this esteem. According to Milton, his dedication to chastity began-improbably—with his reading of romances. In those works, he saw that "the oath of every Knight" required "he should defend to the expence of his best blood ... the honour and chastity of Virgin or Matron. From whence ... I learnt what a noble vertue chastity sure must be." ${ }^{96}$ After a few more sentences on this topic, Milton notes that he received a similarly exalted view of chastity from Greek philosophy, where "the divine volumes of Plato and his equall Xenophon" taught him "of chastity and love.... And how the first and chiefest office of love, begins and ends in the soule." ${ }^{\prime 7}$ Last and least, Milton mentions his religion. "Though Christianity," he says, "had bin but slightly taught me, yet a certain reserv'dnesse of naturall disposition, and morall discipline learnt out of noblest Philosophy was anough to keep me in disdain of farre lesse incontinences then this of the Burdello."98 In other words, Milton claims that he acquired his initial esteem for chastity exclusively from secular and pagan sources.

That is not to say that Christianity played no role in his ideas about sexual continence, but Milton implies that his religion's chief contribution came through his independent study of the Bible. As he continues,

Having had the doctrine of holy Scripture unfolding those chaste and high mysteries with timeliest care infus'd, that the body is for the Lord and the Lord for the body, thus also I argu'd to my selfe; that if unchastity in a woman whom Saint Paul termes the glory of man, be such a scandall and dishonour, then certainly in a man who is both the image and glory of God, it must, though commonly not so thought, be much more deflouring and dishonourable. In that he sins both against his owne body which is the perfeter sex, and his own glory which is in the woman, and that which is worst, against the image and glory of God which is himselfe. Nor did I slumber over that place expressing such high rewards of ever accompanying the Lambe, with those celestiall songs to others inapprehensible, but not to those who were not defil'd with women, which doubtlesse meanes fornication: For marriage must not be call'd a defilement. ${ }^{99}$

There are many strange things about An Apology's lengthy autobiographical passage. Scholars before me have commented on the oddity of Milton's moving from a general defense of his virtue to an extended discussion of his esteem

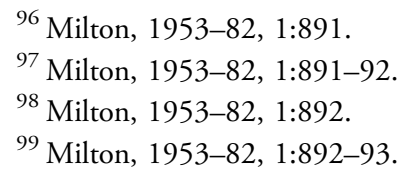


for chastity, specifically, and they have also noted that in the portion I have just quoted Milton seems to be rewriting the positions he took in A Mask, Lycidas, and Damon's Epitaph, where virginity is clearly exalted over mere chastity; writing shortly before his own marriage, Milton's views about sexual continence appear to have shifted. ${ }^{100}$ But just as striking as Milton's silent substitution of chastity for virginity is the way he frames Christian teachings about sexual continence. He seems to be doing everything possible to suggest that his interest was entirely idiosyncratic, the result of his eclectic reading and unmediated interpretation of the Bible ("Christianity had bin but slightly taught me"; "thus also I argu'd to my selfe"; "though commonly not so thought"). And, at least among twentieth- and twenty-first-century readers, this strategy seems to have worked. Those who have considered the question of Milton's attraction to virginity have generally taken his claims at face value, explaining his interest as the private obsession that an unusual and studious mind cobbled together from sources such as Spenser and Plato. ${ }^{101}$

Now, it is certainly possible that pagan sources influenced Milton's thinking about virginity, but it is not possible that the long history of Christian asceticism was as entirely absent as An Apology implies. ${ }^{102}$ Rather, Milton's downplaying of any possible Christian inspiration should be seen as a deliberate rhetorical move. Every one of Milton's seventeenth-century readers would have been aware of an interpretative tradition that read a veneration for celibacy into the Gospels and the Pauline epistles. Protestants knew that Paul was himself a virgin who expressed a preference "that all men were even as I myself," and they knew that that verse, along with the whole of 1 Corinthians 7 , was hotly debated between Protestants and Catholics as to the degree of that preference. They also knew that Revelation 14:1-4 had traditionally been read as asserting the primacy of virginity over married life, as had Jesus's own apparent virginity and several of his statements, including Matthew 22:30 ("for in the resurrection they neither marry, nor are given in marriage"). Nor was male chastity as unusual a subject among English Protestants as Milton implies: university fellows still took vows of celibacy, Laud was a celibate, and Charles was said to have wished that all his clergy might be likewise. Indeed, as John Rogers has

${ }^{100}$ Perhaps the earliest to note this are Hanford, 137-39, 148-50; Tillyard, 323.

${ }^{101}$ See, for example, Hanford, 138-45. Rogers, whose analysis of $A$ Mask does give sustained attention to Christian sexual asceticism in late antiquity as well as among radical Protestants (and, to a lesser degree, natural philosophers) in the 1640s and 1650s, nevertheless does not weigh in on the question of Milton's own influences.

${ }^{102}$ Indeed, the similarities between Christian asceticism and the pagan variety come up frequently in the writings of the fathers. In Against Jovinian, Jerome provides long lists of pagan ascetics, including the vestal virgins, Plato, and the Stoics. See Jerome, 1994b, 6:379, 395-96 (Jovinian 1.41, 2.9-11). 
pointed out, during the Civil War even more radical Protestants sometimes advocated sexual asceticism. ${ }^{103}$

But Milton acknowledges neither an older Christian tradition of male chastity nor any present-day survivals or revivals. In the context of the Apology's selfdefense, Milton's immediate rhetorical goal may be emphasizing the intensity of his commitment to chastity, the better to counter his opponent's claims of licentiousness. However, as I am suggesting, the nature of that commitment remains peculiar. By 1642 Milton may have modified his reading of Revelation 14:1-4 to include the virtuous married, but, in contrast to Bale and commentators in his tradition, he still insists that some form of sexual purity is a prerequisite for a reward that he continues to figure as celestial song. In this Milton remains far more indebted to Jerome's defenses of virginity than to any Protestant commentaries on the Apocalypse.

\section{GLORIOUS EREMITES}

Just as Milton remains indebted to Jerome, however, he remains cagey about those debts. Milton's critiques of Jerome do increase after his marriage and his abandonment of any personal commitment to virginity, but Jerome's influence does not so much wane as it changes shape; Milton's attempts to domesticate and rehabilitate Jerome further demonstrate the vexed status of patristic authority in Protestant England. I have already noted how frequently Milton has recourse to Jerome's authority in the divorce tracts despite those works' many references to the importance of a helpmeet and even to the sexual side of that help, ${ }^{104}$ and in Areopagitica he makes a similar move, commenting snidely on Jerome's "lenten" asceticism, and yet—in a passage that I will discuss more fully in a moment-he is unable to dismiss the divine vision Jerome's asceticism produces. ${ }^{105}$ In Paradise Lost I believe this pattern continues: Jerome remains a vital intellectual presence, simultaneously relied upon and rejected.

The rejection is initially the more obvious. First there is book 3's jeering reference to the "Embryos, and Idiots, Eremites and Friars" who populate the Paradise of Fools, and then there is the poem's enthusiastic depiction of wedded

${ }^{103}$ Rogers, 233-41.

${ }^{104}$ As Luxon, 57-93, notes, Milton's intense focus on conversation as the chief end of marriage is ambiguous. Milton does mean that spouses should delight in talking to one another, but, like intercourse, conversation had a double meaning in the period.

${ }^{105}$ Milton, 1953-82, 2:510. For a fuller discussion of this passage from Eustochium and Milton's account of it in Areopagitica, see below. 
love. ${ }^{106}$ In book 4, the narrator makes clear that Adam and Eve are not virgins and then attacks those who might say otherwise:

Whatever Hypocrites austerely talk

Of purity and place and innocence, [they are]

Defaming as impure what God declares

Pure, and commands to some, leaves free to all. ${ }^{107}$

In insisting on prelapsarian sex, Milton dismisses the arguments of those who, like Jerome, claimed that sex was a result of the Fall; this passage may even contain an ironic swipe at Jerome and his proof texts. Whereas Jerome argues from 1 Corinthians 7:25 that virginity, though not commanded, is purer and more commendable precisely because it is not commanded, Milton reverses Jerome's emphasis, saying that marriage is indeed pure, and commanded to some, though available to all. ${ }^{108}$ But it might be more accurate to say that the mature Milton wrestles with and revises Jerome rather than refuting him outright. Like Jerome in Against Jovinian, Milton sees the Fall as a failure of temperance, and like Jerome he believes that Adam and Eve did not drink alcohol or eat meat in Eden. ${ }^{109}$ The first couple does have sex, but Milton is at pains to distinguish the lustful postlapsarian variety from the prelapsarian. And although Paradise Lost's insistence on the sexuality of the angels could be read as a rebuke to Jerome's reading of Matthew 22:30, in which the angels are sexless and unmarried and Jesus asserts that in heaven all humans will be likewise, this too may be read as an emendation rather than a rejection. ${ }^{110}$ In Milton's Eden virgins do not become like the angels, but Raphael tells the prelapsarian Adam and Eve that married chastity, combined with other forms of temperance, will indeed bring them to the angels' blissful and ambisexual estate. ${ }^{111}$ What Jerome claimed was possible only for the purest of virgins, Milton expands to the married but

${ }^{106}$ Milton, 1957, 269 (Paradise Lost 3.474). That Paradise Lost's treatment of wedded love and angelic sex represents a repudiation of Milton's early interest in virginity is a commonplace; see, e.g., Kerrigan, 69-72.

${ }^{107}$ Milton, 1957, 295-96 (Paradise Lost 4.744-47).

108 "And therefore Christ loves virgins more than others, because they willingly give what was not commanded them": Jerome, 1994b, 6:355 (Jovinian 1.12).

${ }^{109}$ The second book of Jovinian is primarily concerned with dietary temperance-especially the importance of avoiding meat and alcohol—as well as the connection between fasting and sexual abstinence. For this line of argument, see Jerome, 1994b, 6:391-400 (Jovinian 2.5-15).

110 "What others will hereafter be in heaven, that virgins begin to be on earth. If likeness to the angels is promised us (and there is no difference of sex among the angels), we shall either be of no sex as are the angels, or at all events ... we shall not perform the functions of sex": Jerome, 1994b, 6:374 (Jovinian 1.36).

${ }^{111}$ See Milton, 1957, 313-14 (Paradise Lost 5.469-503). 
equally pure. Just as in his early poems, Milton remains committed to bodily self-discipline and a believer in its potential for both spiritual and ontological transformation. ${ }^{112}$

But if it is possible to read Adam and Eve as Milton's adaptation of Jerome for Protestant circumstances, in his final poems Milton more clearly returns to Jerome's ascetic vision. Both the Son in Paradise Regain'd and Samson are, in different ways, celibates who triumph over fleshly temptation. Paula Loscocco has argued that Samson's rejection of Dalilah is a "final recovery of Nazarite separation," with his newfound chastity enabling the poem's apocalyptic end. ${ }^{113}$ However, it is Paradise Regain'd that provides Milton with a truly Jeromian hero, one commensurate with the promises laid out and only partially fulfilled in A Mask. Readers have long recognized that the Son's resistance to Satan's temptations is continuous with the themes of Milton's earlier work, but they have not commented on the fact that the Son, too, is a virgin, or observed the poem's considerable investment in monastic language and imagery.

These investments are not far to seek. In the poem's first lines Milton refers to the Son as "that glorious Eremite," 114 and the work's desert setting is, as N. H. Keeble has noted, given unusually elaborate description. ${ }^{115}$ Milton's expansion of Jesus's temptations well beyond the Gospel accounts also seems indebted to the literature of desert monasticism, in which frightening visions and demonic appeals to pride, greed, and the appetites are routine features. I noted one instance of this in Jerome's reference in Eustochium to his temptation by "bevies of girls," but assaults by demons, wild animals, and the devil himself can be found throughout early eremitic biographies, including two in which Jerome had a hand: Athanasius's Life of Antony of Egypt, which Jerome translated into Latin, and Jerome's own Life of Paul the Hermit. The extra-biblical

${ }^{112}$ For other patristic sources on the difficulty of bodily temperance that may have influenced Milton, see Poole, 9-14.

${ }^{113}$ In making this argument, Loscocco makes an explicit link between Samson and the Lady. Although Samson is not a virgin, as a Nazarite he grew up bound by "vow of strictest purity" and laments that "this temperance [was] not compleat / Against another object more enticing"-which is to say, his wife: Milton, 2008, 80, 86-87 (Samson 319, 558-59). Loscocco seems to believe that Samson broke an original vow of virginity (an idea that is not in Judges and is probably a tendentious reading of Milton); however, one need not accept that particular reading in order to agree that the poem valorizes his later-life turn toward chastity and even presents it as a necessary condition for his apocalyptic redemption.

${ }^{114}$ Milton, 2008, 5 (Paradise Regain'd 1.8).

${ }^{115}$ Keeble argues that the poem's desert is a timeless, typological wilderness that connects the Son's temptations to the wanderings of the Israelites and the fasting of Elijah—as well as to the trials of the godly after the Restoration. See also Lewalski, 1966, 196-204. 
temptations of Paradise Regain'd are likewise all appeals to the Son's human nature. ${ }^{116}$ For example, the temptation to turn stones into bread, which in Matthew is only ambiguously a temptation for Jesus to relieve his own hunger and in Luke seems primarily a temptation to show off by working a miracle, in Milton's hands is transformed into Satan's attempt to prey upon the Son's hunger, then upon his imagined desire to feed others, and finally upon his other appetites, with an elaborate banquet attended by male and female servers no less delectable than the food. ${ }^{117}$ These temptations, like the dreams that Satan sends the Son and the storms he conjures up, have no analogue in the Gospels but are staples of the literature of desert asceticism.

But if many of the poem's details seem inspired by early Christian ascetic lore, the Temptation of the Kingdoms returns us to Jerome specifically. In that strange middle portion of the temptation, after the Son has rejected empire and military might, Satan shows him Athens and urges him to "be famous ... I By wisdom." As he argues,

All knowledge is not couch't in Moses Law

The Pentateuch or what the Prophets wrote,

The Gentiles also know, and write, and teach

To admiration. ${ }^{118}$

Critics have tended to regard this temptation as a particularly personal one for Milton, but it was probably derived most immediately from Jerome. ${ }^{119}$ In Eustochium's most famous passage - the passage that Milton references in Areopagitica and that Erasmus complained was the one part of Jerome that everyone knew ${ }^{120}$ _ Jerome describes what he regarded as his most grievous

${ }^{116}$ The extra-biblical temptations, and their possible analogues, are discussed at length in Lewalski, 1966, 193-321. More recent attempts to explain or find analogues include W. B. Hunter; Babcox; Knoppers.

${ }^{117}$ Milton, 2008, 14, 29-30 (Paradise Regain'd 1.338-45, 2.337-67). For more on the demonic temptation of ascetics—including by sexualized servant boys and girls—see Brakke.

${ }^{118}$ Milton, 2008, 53 (Paradise Regain'd 4.221-22, 225-28).

${ }^{119}$ Indeed, it has also felt personal for many critics. See, e.g., Rajan. Lewalski itemizes a number of earlier, similar reactions: Lewalski, 1966, 282. Festa has perceptively discussed the way this temptation intersects with Milton's apparent attempts, in Paradise Regain'd, to write an epic less beholden to pagan or secular models than was Paradise Lost.

120 "This is that account which everyone remembers, even those who have never read a single word of the writings of Jerome. He was flogged, they say, because he had read Cicero. And out of a marvelous devotion, as it were, they shun all good literature. They have nothing to do with it lest by chance unwittingly they might come upon some word of Cicero and be flogged with Jerome. At the same time they consider themselves very close to the apostles if their language is as coarse as possible": Brady and Olin, 190 (and see also 50-51). 
temptation. Even after he was a relatively experienced ascetic and had left his family and friends and settled in the Syrian desert, he says, "I still could not bring myself to forego the library which I had formed for myself at Rome with great care and toil. And so, miserable man that I was, I would fast only that I might afterwards read Cicero. After many nights spent in vigil, after floods of tears ... I would once more take up Plautus. And when at times I returned to my right mind, and began to read the prophets, their style seemed rude and repellent." ${ }^{121}$ Eventually Jerome falls into a terrible sickness during Lent and is "caught up in the spirit and dragged before the judgment seat of the Judge. ... Asked who and what I was I replied: 'I am a Christian.' But $\mathrm{He}$ who presided said: 'Thou liest, thou art a follower of Cicero and not of Christ." 122 Jerome is scourged for his sins, but eventually God has pity on him. Jerome forswears pagan literature on the spot.

This passage understandably gave humanists some trouble. Elsewhere Jerome insists that Christians may make free use of pagan literature, ${ }^{123}$ and he cites it in many works later than Eustochium, which suggests that he was still reading it. These facts, combined with a later work in which Jerome describes his appearance before God's judgment seat as "a mere dream" (rather than a true vision, as he implied in Eustochium), led Erasmus and others to conclude that in his earlier work Jerome had been exaggerating to make a rhetorical point to his young female addressee. ${ }^{124}$ The real message of the story, according to Erasmus, was that one should not misuse or overvalue secular literature. ${ }^{125}$

Milton's reference to this passage in Areopagitica suggests that in 1643 he agreed with Erasmus's reading, although his own account of Jerome's vow is notable for its defensiveness. He begins by dismissing the episode as "a lenten

${ }^{121}$ Jerome, 1994b, 6:35 (Eustochium 30).

122 Jerome, 1994b, 6:35-36 (Eustochium 30).

${ }^{123}$ See Jerome, 1994b, 6:89-96 and 149-51 (epistles 52 and 70, to Nepotian and Magnus, respectively). In the former, Jerome insists on the sufficiency of scripture-but he does so in a letter full of casual references to and quotations from Virgil, Cicero, Homer, and Sophocles. In the latter, a favorite of Renaissance humanists, Jerome compares pagan literature to the foreign woman whom Moses says an Israelite may lawfully take to wife after her hair has been shaved and nails pared (Deuteronomy 21:10-13).

${ }^{124}$ In his Apology against Rufinus, Jerome responds at length to Rufinus's accusations that he has violated the vow he made in his vision. Without ever acknowledging that he has resumed reading pagan literature-he says, in part, that he learned pagan literature so well in his youth that his head is a permanent storehouse-Jerome insists that one cannot be bound by things that occur in dreams. See Jerome, 1994a, 3:499 (Rufinus 1.30-31). For a fuller account of Jerome's vision, vow, and later descriptions of the episode, see Kelly, 41-44.

${ }^{125}$ See Brady and Olin, 50-52, 190. Erasmus was not the first to propose this reading, however, as Gratian says something similar in the twelfth century. See Gratian (Decretum 1.37.7). 
dream ... or else a fantasm bred by the feaver which had then seis'd [Jerome]" but then, surprisingly, makes Jerome's scourger "the Divell" rather than the angel Jerome implies in Eustochium. ${ }^{126}$ In making this switch, Milton may be suggesting that what Jerome actually experienced was a satanic temptation to do what he should not-which is to say, give up pagan literature. As Milton notes in Areopagitica's immediately preceding example, Julian the Apostate forbade Christians "the study of heathen learning," which the faithful considered "a persecution more undermining and secretly decaying the Church, then the open cruelty of Decius or Dioclesian," and the abrupt shift from this episode to Jerome's "fantasm" implies a relationship between the two. ${ }^{127}$ Enlisting this passage from Eustochium in support of Areopagitica's argument that to the pure all books are pure would be an extraordinary reading of Jerome; perhaps in acknowledgment of that fact, Milton briefly considers the possibility that Jerome's scourger might have been an angel after all, but concludes that that wouldn't make any sense: why would an angel scourge Jerome for reading Cicero, but not Plautus? And why pick on Jerome rather than so many other fathers? ${ }^{128}$ Finally, Milton seems to admit that Jerome described the episode as a true vision, but he does so only to undercut the authority of that vision by contrasting Jerome's with the "far ancienter" vision of Dionysius of Alexandria, in which the latter was told that he might read any books he liked, being himself "sufficient ... to judge aright." ${ }^{29}$ In short, in Areopagitica Milton seems to want very badly to present Jerome, the "learned'st of the Fathers," as an example of the value of reading widely—or if he cannot, to reject his story utterly. ${ }^{130}$ But he cannot quite do either.

In Paradise Regain'd Milton resolves the matter very differently. The Son's reply to Satan starts off evasively, leaving open the possibility that he is taking

${ }^{126}$ Milton, 1953-82, 2:510. Eustochium does not precisely identify the scourger, but it seems to be one of the "radiant" creatures around God's judgment seat: Jerome, 1994b, 6:35 (Eustochium 30).

${ }^{127}$ Milton, 1953-82, 2:508-10. The syntax at this point in the tract is difficult to parse. Immediately after the statement that Julian's policy was considered worse than the persecution of Decius and Diocletian, Milton says, "And perhaps it was the same politick drift that the Divell whipt St. Jerom in a lenten dream, for reading Cicero." My reading is that Milton is relating the two episodes, comparing the devil to Julian the Apostate in his desire to prevent Christians from reading useful pagan literature.

${ }^{128}$ Milton, 1953-82, 2:510.

${ }^{129}$ Milton, 1953-82, 2:511. Milton does not acknowledge that he has previously called Jerome's vision a dream. Instead, abruptly changing the subject, he writes: "But if it be agreed we shall be try'd by visions, there is a vision recorded by Eusebius far ancienter then this tale of Jerom to the Nun Eustochium," and proceeds to recount the vision of Dionysus of Alexandria.

${ }^{130}$ Milton, 1953-82, 1:776-77. 
the Areopagitican position that the only thing wrong with the writing of the gentiles is when it is elevated above scripture: "Think not but that I know these things, or / Think I know them not; not therefore am I short / Of knowing what I aught." 131 Although the Son is clearly unmoved by Satan's temptation, the passage's negative constructions and heavy enjambment mean it is not immediately clear what he thinks of pagan literature; in these first lines he does not dismiss its worth and even implies that he might already be well versed in the learning of the gentiles. But any impression of tolerance is dashed by the next seventy-five lines, in which the Son details exactly how worthless every form of pagan learning is in comparison with scripture. This is by far the Son's longest response to Satan in the poem, suggesting just how thorough Milton wished for the Son's rejection to be (and perhaps also how appealing Milton found the temptation). ${ }^{132}$ Just as the Jerome of Eustochium utterly renounces pagan literature, so too does the Son. Perhaps Milton's understanding of Jerome's vow had changed since Areopagitica, or perhaps he always saw it as a splendid renunciation, fit for a hero, but not something that should serve as a rule to all.

At the poem's end the ascetic, eremitic Son-fasting, virginal, unmoved by any fleshly or worldly temptation-stands as the fulfillment of all Jerome's promises. Not only does he receive the kind of angelic assistance that the Lady and Elder Brother describe as the true virgin's reward, but in the song of the heavenly host the reader learns that the Son has reversed the Fall, will achieve victory over death, and will bring about the eventual Apocalypse. ${ }^{133}$ Of course, the Son is no ordinary virgin, and neither in the New Testament nor in Milton's poem is his virginity presented as the cause of any of his remarkable achievements. However, the connections between this poem and A Mask, and their shared investment in Jerome's defenses of virginity, suggest that Milton never abandoned his interest in Jerome-nor even his interest in sexual asceticism. In later life he simply reconfigured that asceticism into the abstemious behavior of the prelapsarian Adam and Eve; the flawed but finally celibate Samson; and, most clearly, the one virgin whose apocalyptic powers were uncontested and unproblematic, the Son of God himself. No Protestant could object to that particular virgin.

${ }^{131}$ Milton, 2008, 55 (Paradise Regain'd 4.286-88).

132 The entire speech amounts to seventy-eight lines, making it almost 20 percent longer than the Son's next longest exchange with Satan. The only time he speaks at greater length is in book 1's opening monologue.

${ }^{133}$ Milton, 2008, 63-64 (Paradise Regain'd 4.596-635). 


\section{BIBLIOGRAPHY}

Adkin, Neil. Jerome on Virginity: A Commentary on the "Libellus de virginitate servanda" (Letter 22). Cambridge: Francis Cairns, 2003.

Ante-Nicene Christian Library. Ed. Alexander Roberts and James Donaldson. 10 vols. Peabody, MA: Hendrickson, 1994.

The Apocalypse in English Renaissance Thought and Literature: Patterns, Antecedents, and Repercussions. Ed. C. A. Patrides and Joseph Wittreich. Ithaca, NY: Cornell University Press, 1984.

Augustine. The Works of Saint Augustine: Marriage and Virginity. Trans. Ray Kearney. Hyde Park, NY: New City Press, 1999.

Babcox, Emilie. "Physical and Metaphorical Hunger: The Extra-Biblical Temptations of Paradise Regained." Milton Quarterly 26.2 (1992): 36-42.

Bale, John. Image of Both Churches. London, 1550.

Brady, James F., and John C. Olin, eds. Collected Works of Erasmus, Vol. 61: The Edition of St. Jerome. Toronto: University of Toronto Press, 1992.

Brakke, David. Demons and the Making of the Monk: Spiritual Combat in Early Christianity. Cambridge, MA: Harvard University Press, 2006.

Brightman, Thomas. A Revelation of the Apocalypse. Amsterdam, 1611.

Brogan, Boyd. "The Masque and the Matrix: Alice Egerton, Richard Napier, and Suffocation of the Mother." Milton Studies 55 (2014): 3-52.

Broughton, Hugh. A Revelation of the Holy Apocalypse. Middleburg, 1610.

Brown, Peter. The Body and Society: Men, Women, and Sexual Renunciation in Early Christianity. London: Faber \& Faber, 1988.

Calvin, John. Institutes of the Christian Religion. Trans. Henry Beveridge. Grand Rapids, MI: William B. Eerdmans, 1989.

Campbell, Gordon, and Thomas N. Corns. John Milton: Life, Work, and Thought. Oxford: Oxford University Press, 2008.

Capp, Bernard. "The Political Dimension of Apocalyptic Thought." In The Apocalypse in English Renaissance Thought and Literature (1984), 93-124.

Cefalu, Paul. The Johannine Renaissance in Early Modern English Literature and Theology. Oxford: Oxford University Press, 2017.

Cyprian. On the Dress of Virgins. Trans. Ernest Wallis. In Ante-Nicene Christian Library (1994), 5:430-36.

Dent, Arthur. The Ruine of Rome: or an Exposition upon the Whole Revelation. London, 1603.

Duval, Yves-Marie. L'affaire Jovinien: D'une crise de la société romaine à une crise de la pensée chrétienne à la fin du $I V^{\mathrm{e}}$ et au début du $V^{\grave{e}}$ siècle. Rome: Institutum Patristicum Augustinianum, 2003.

Emmerson, Richard K. "The Apocalypse in Medieval Culture." In The Apocalypse in the Middle Ages, ed. Richard K. Emmerson and Bernard McGinn, 293-332. Ithaca, NY: Cornell University Press, 1992.

Ettenhuber, Katrin. Donne's Augustine: Renaissance Cultures of Interpretation. Oxford: Oxford University Press, 2011. 
Evans, J. Martin. The Road from Horton: Looking Backwards in "Lycidas.” Victoria, BC: English Literary Studies, 1983.

Festa, Thomas. "The Temptation of Athens and the Variorum Paradise Regained." Huntington Library Quarterly 76.1 (2013): 11-33.

Firth, Katharine R. The Apocalyptic Tradition in Reformation Britain, 1530-1645. Oxford: Oxford University Press, 1979.

Gratian. Decretum. Ed. Emil Friedberg. In Corpus Iuris Canonici, vol. 1. Leipzig: Bernhard Tauchnitz, 1879. Online edition hosted by Bayerische Staatsbibliothek: http://geschichte. digitale-sammlungen.de/decretum-gratiani//text.

Greteman, Blaine. “Perplex’t Paths': Youth and Authority in Milton's Mask.” Renaissance Quarterly 62.2 (2009): 410-43.

Halpern, Richard. "Puritanism and Maenadism in A Mask." In Rewriting the Renaissance: The Discourse of Sexual Difference in Early Modern Europe, ed. Margaret W. Ferguson, Maureen Quilligan, and Nancy J. Vickers, 88-105. Chicago: University of Chicago Press, 1986.

Hanford, James Holly. "The Youth of Milton: An Interpretation of His Early Literary Development." In Studies in Shakespeare, Milton, and Donne, ed. Members of the English Department of the University of Michigan, 89-163. New York: Macmillan, 1925.

Hawkins, Peter S. Dante's Testaments: Essays on Scriptural Imagination. Stanford, CA: Stanford University Press, 1999.

Hunter, David G. Marriage, Celibacy, and Heresy in Ancient Christianity: The Jovinianist Controversy. Oxford: Oxford University Press, 2007.

Hunter, William B., Jr. "The Double Set of Temptations in Paradise Regained." Milton Studies 14 (1980): 183-93.

Jardine, Lisa. Erasmus, Man of Letters: The Construction of Charisma in Print. Princeton, NJ: Princeton University Press, 1993.

Jerome. Apology for Himself against the Books of Rufinus. Trans. W. H. Freemantle. In Nicene and Post-Nicene Fathers, Second Series (1994a), 3:482-541.

Letters and Select Works. Trans. W. H. Freemantle. In Nicene and Post-Nicene Fathers, Second Series (1994b), vol. 6.

Jue, Jeffrey K. Heaven upon Earth: Joseph Mede (1586-1638) and the Legacy of Millenarianism. Dordrecht: Springer, 2006.

Junius, Franciscus. The Apocalyps. Cambridge, 1596.

Keeble, N. H. "Wilderness Exercises: Adversity, Temptation, and Trial in Paradise Regained." Milton Studies 42 (2003): 86-105.

Kelly, J. N. D. Jerome: His Life, Writings, and Controversies. London: Duckworth, 1975.

Kendrick, Christopher. "Milton and Sexuality: A Symptomatic Reading of Comus." In Re-Membering Milton: Essays on the Texts and Traditions, ed. Mary Nyquist and Margaret W. Ferguson, 43-73. New York: Methuen, 1987.

Kerrigan, William. The Sacred Complex: On The Psychogenesis of "Paradise Lost. "Cambridge, MA: Harvard University Press, 1983.

Kim, Julie H. "The Lady's Unladylike Struggle: Redefining Patriarchal Boundaries in Milton's Comus.” Milton Studies 35 (1997): 1-20. 
Knoppers, Laura Lunger. "Satan and the Papacy in Paradise Regained." Milton Studies 42 (2003): 68-85.

Lander Johnson, Bonnie. Chastity in Early Stuart Literature and Culture. Cambridge: Cambridge University Press, 2015.

Leonard, John. "Milton's View of Celibacy: A Reconsideration of the Evidence." In Of Poetry and Politics: New Essays on Milton and His World, ed. P. G. Stanwood, 187-201. Binghamton, NY: Medieval and Renaissance Texts and Studies, 1995.

Lewalski, Barbara Kiefer. Milton's Brief Epic: The Genre, Meaning, and Art of "Paradise Regained." Providence, RI: Brown University Press, 1966.

- Life of John Milton. Malden: Blackwell, 2005.

Loscocco, Paula. “'Not Less Renown'd than Jael': Heroic Chastity in Samson Agonistes.” Milton Studies 40 (2002): 181-200.

Lössl, Josef. "Martin Luther's Jerome: New Evidence for a Changing Attitude." In Jerome of Stridon: His Life, Writings, and Legacy, ed. Andrew Cain and Josef Lössl, 237-51. Farnham: Ashgate, 2009.

Luxon, Thomas H. Single Imperfection: Milton, Marriage, and Friendship. Pittsburgh, PA: Duquesne University Press, 2005.

Lyra, Nicholas of. Nicholas of Lyra's Apocalypse Commentary. Ed. and trans. Philip D. W. Krey. Kalamazoo, MI: Medieval Institute Publications, 1997.

McManamon, John M. "Pier Paolo Vergerio (The Elder) and the Beginnings of the Humanist Cult of Jerome." Catholic Historical Review 71.3 (1985): 353-71.

Mede, Joseph. The Key of the Revelation. Trans. Richard More. London, 1643.

Methodius. The Banquet of the Ten Virgins. Trans. William R. Clark. In Ante-Nicene Christian Library (1994), 6:309-55.

Milton, John. Complete Prose Works of John Milton. Ed. Don M. Wolfe et al. 8 vols. New Haven, CT: Yale University Press, 1953-82.

- Complete Poems and Major Prose. Ed. Merritt Y. Hughes. New York: Macmillan, 1957.

- A Mask: The Earlier Versions. Ed. S. E. Sprott. Toronto: University of Toronto Press, 1973.

- Complete Works of John Milton. Vol. 2: The 1671 Poems "Paradise Regain'd" and "Samson Agonistes." Ed. Laura Lunger Knoppers. Oxford: Oxford University Press, 2008.

- Complete Works of Milton. Vol. 3: The Shorter Poems. Ed. Barbara Kiefer Lewalski and Estelle Haan. Oxford: Oxford University Press, 2012.

Netzley, Ryan. Lyric Apocalypse: Milton, Marvell, and the Nature of Events. New York: Fordham University Press, 2015.

Nicene and Post-Nicene Fathers, Second Series. Ed. Philip Schaff and Henry Wace. 14 vols. Peabody, MA: Hendrickson, 1994.

Orgel, Stephen. "The Case for Comus." Representations 81 (2003): 31-45.

Pabel, Hilmar M. "Reading Jerome in the Renaissance: Erasmus' Reception of the Adversus Jovinianum.” Renaissance Quarterly 55.2 (2002): 470-97.

Herculean Labours: Erasmus and the Editing of St. Jerome's Letters in the Renaissance.

Leiden: Brill, 2008. 
Poole, Kristen. “'With Such Joy Surcharg'd': The Predicament of Satiety in Patristic Theology and Paradise Lost." Milton Quarterly 49.1 (2015): 1-22.

Pritchard, John Paul. "The Fathers of the Church in the Works of John Milton." Classical Journal 33.2 (1937): 79-87.

Pseudo-Sulpitius Severus. The Works of Sulpitius Severus. Trans. Alexander Robbins. In Nicene and Post-Nicene Fathers, Second Series (1994), 11:1-120.

Quantin, Jean-Louis. The Church of England and Christian Antiquity: The Construction of a Confessional Identity in the 17th Century. Oxford: Oxford University Press, 2009.

Quint, David. "Expectation and Prematurity in Milton's Nativity Ode." Modern Philology 97.2 (1999): 195-219.

Rajan, Balachandra. "Jerusalem and Athens: The Temptation of Learning in Paradise Regained." In Th'upright Heart and Pure: Essays on John Milton Commemorating the Tercentenary of the Publication of Paradise Lost, ed. Amadeus P. Fiore, 61-74. Pittsburgh, PA: Duquesne University Press, 1967.

Rice, Eugene F., Jr. Saint Jerome in the Renaissance. Baltimore, MD: Johns Hopkins University Press, 1985.

Rogers, John. "The Enclosure of Virginity: The Poetics of Sexual Abstinence in the English Revolution." In Enclosure Acts: Sexuality, Property, and Culture in Early Modern England, ed. Richard Burt and John Michael Archer, 229-50. Ithaca, NY: Cornell University Press, 1994.

Sandler, Florence. "The Faerie Queene: An Elizabethan Apocalypse." In The Apocalypse in English Renaissance Thought and Literature (1984), 148-74.

Saurat, Denis. Milton: Man and Thinker. New York: Dial, 1925.

Shaw, Teresa M. The Burden of the Flesh: Fasting and Sexuality in Early Christianity. Minneapolis, MN: Fortress, 1998.

Shuger, Debora. "'Gums of Glutinous Heat' and the Stream of Consciousness: The Theology of Milton's Maske." Representations 60 (1997): 1-21.

. "Milton's Religion: The Early Years." Milton Quarterly 46.3 (2012): 137-53.

Shullenberger, William. "Into the Woods: The Lady's Soliloquy in Comus." Milton Quarterly 35.1 (2001): 33-43.

. "Girl, Interrupted: Spenserian Bondage and Release in Milton's Ludlow Mask." Milton Quarterly 37.4 (2003): 184-204.

Silvia, D. S., and John P. Brennan. "Medieval Manuscripts of Jerome Against Jovinian." Manuscripta 13 (1969): 161-66.

Sirluck, Ernest. "Milton's Idle Right Hand.” Journal of English and Germanic Philology 60 (1961): 749-85.

Smectymnuus. Answer to a Booke Entitled an Humble Remonstrance. London, 1641a.

- Vindication of the Answer to a Book. London, 1641b.

Smith, Warren S. "The Wife of Bath Debates Jerome." Chaucer Review 32.2 (1997): 129-45.

Smyth, John. The Character of the Beast. Middleburg, 1609.

Spenser, Edmund. The Faerie Queene: Book One. Ed. Carol V. Kaske. Indianapolis, IN: Hackett, 2006.

Thomas, Catherine. "Chaste Bodies and Poisonous Desires in Milton's Mask." Studies in English Literature 46.2 (2006): 435-59. 
Tillyard, E. M. W. Milton. London, 1930. Rev. ed., London: Macmillan, 1966.

Verie Plaine and Well-Grownded Treatise Concerning Baptisme. [Netherlands?], 1618.

Visser, Arnoud. Reading Augustine in the Reformation: The Flexibility of Intellectual Authority in Europe, 1500-1620. Oxford: Oxford University Press, 2011.

. "Irreverent Reading: Martin Luther as an Annotator of Erasmus." Sixteenth Century Journal 48.1 (2017): 87-109.

Wittreich, Joseph Anthony, Jr. Visionary Poetics: Milton's Tradition and His Legacy. San Marino, CA: Huntington Library, 1979. 